\title{
Compound Words in Arabic Mechanical Term
}

\author{
Darsita Suparno ${ }^{1, *}$ Yani'ah Wardhani ${ }^{2}$, Agus Nuryana ${ }^{3}$, Nuryani $^{4}$
}

\author{
${ }^{1}$ UIN Syarif Hidayatullah Jakarta \\ ${ }^{2}$ UIN Syarif Hidayatullah Jakarta \\ ${ }^{3}$ UIN Syarif Hidayatullah Jakarta \\ ${ }^{4}$ UIN Syarif Hidayatullah Jakarta \\ *Corresponding author. Email: darsitasuparno@uinjkt.ac.id
}

\begin{abstract}
The paper reports on the results of a study purposing to observe the compound words in Modern Arabic Standard (MSA) found in Dictionaries of Arabic Mu'jam Handasat al-Mikanik al-Musowir in the subject of lexicography at $4^{\text {th }}$ semester in the Arabic Translation Department. This study is purposed to describe what the forms of compound words are and what the meaning is by using Yule's theory and Nick Riemer' theory. The criteria are used in this study are orthographic, phonological, syntactic and semantics in nature which to make the distinction between compounds and phrases. This study uses a descriptive qualitative view. The source of data is text or words. The subject in this study is Arabic forms of compound words. The data is collected by using the documentation method. There are several procedures to collect the data: reading the CNN Arabic newspaper, reading the dictionaries, selecting compound words, and retyping. The data is analyzed by using tree diagram Plag's theory and identifying meaning using Nick Riemer's theory. The analysis reveals that the most reliable linguistics criteria: a) adjacency shows that no intervening elements can be inserted between the head and the non-head of compounds, b) referential reveals that insertion is allowed in the phrase. Based on the form of a compound word, there are noun compound, verb compound and conjunctive compound words.
\end{abstract}

Keywords: mechanic, Arabic, form and meaning, compound words.

\section{INTRODUCTION}

The development of Arabic vocabularies especially word compounds increases rapidly in the industrial era 4.0. It has known through the internet, social media, textbooks, newspaper, and dictionaries. Therefore, extracting these word compounds into meaningful information is an important aspect. Mechanical field word compounds often appear in Arabic texts, which make these words have an important role. Compounding is a very productive word-formation process in many Arabic languages as stated by Najar et al., [1]), (Altakhaineh, [2]), (Altakhaineh \& Zibin, [3]), (Mezghanni \& Gargouri [4]) Compound words abundance in Modern Arabic Standard (MSA). These two words often appear together to express meaning and reference. In the field of mechanics, there is not a synonym for the word compound, such as which means 'bimetal shell.' Finally, despite the development of vocabulary, there is a lack of available resources from Arabic compounds. It is necessary to study compound words.

There are many compound words found in CNN Arabic newspaper and Dictionaries of Arabic Mu'jam Handasat al-Mikanik al-Musowir in the subject of lexicography at $4^{\text {th }}$ semester in the Arabic Translation Department. Dictionaries of Arabic Mu'jam Handasat al-Mikanik al-Musowir is a dictionary for the mechanical term for teaching-learning activity in Arabic Translation Department. Automatically, this dictionary uses the Arabic language. There are two reasons why these mechanic terms are interesting to study. First, the Dictionary of Arabic Mu'jam Handasat al-Mikanik alMusowir uses the Arabic language. This dictionary facilitates people to find Arabic mechanic terms. Second, there are many compound words found in this

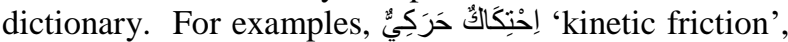

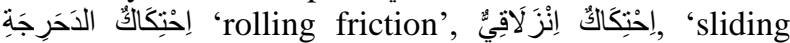

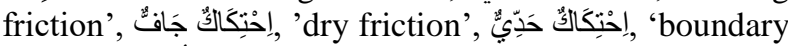

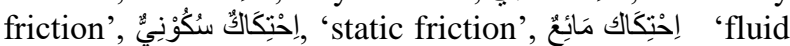
friction'. Data have been studied from the morphology point of view. Based on the explanation of the background of the study, the problem to be analyzed in this paper is formulated as follow: 1) what are the types of compound word in Arabic mechanic term? 2) how is the compound word represented to convey the Arabic mechanic term?

Morphology is the study of word formation, including new ways words are created in world languages, and ways the words formed vary depending 
on how they are used in the sentence, Morphology is the study of word formation, including new ways words are created in world languages, and ways the words formed vary depending on how they are used in the sentence, [5]; [6]); [7]. Morphology is the study of the internal structure of words as described by (Haspelmath \& Sims, [7]), (Yule, [8]. Morphemes can be divided into bound, free, and zero morphemes. A free morpheme may constitute a word (free form) by itself, [8]; [9]; [10].

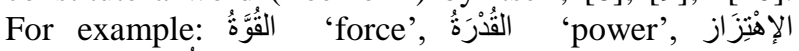
'vibration', النَرَدُدُ 'frequency' etc. Abound morpheme must appear with at least one other morpheme, bound or free, in word [8]; 11]. Such as عمارة t this word consists of عمارات 'apartment building' as free morpheme and $:$ is bound morpheme. A zero morpheme is a zero allomorph without phonemic content, for example, the zero plural and singular have the same form such as تواليت مرق [maraq tuwalitt] 'toilet paper'; سفنج [safanij] 'sponge'; فرش مرشاة [furšaah] 'brush.'

According to (Lieber [6]) a morphological process is a process of forming new words by modifying a morpheme or morphemes. The following are morphological processes: addition or affixation, reduplication, replacement, cliticization, stress and tone replacement, borrowing, clipping, and compounding. The compound word consists of the addition of stems in which a word is formed by the combination of two independent words. The parts of the compound can be free morpheme, derivative word, or another compound [8]; [7]; [12]; [13]. Compounding is a process of combining lexical categories (Noun, Verb, Adjective, or Preposition.) to create a larger word and the resultant meaning is new or different from its element [15]; [14]).

The examples in table 1 as the below:

Table 1. Free morpheme

\begin{tabular}{|c|c|c|c|c|}
\hline No & Gloss & IPA & $\begin{array}{l}\text { Lexical } \\
\text { category }\end{array}$ & meaning \\
\hline 1. & إِحْنِكَاكَ & [iḥtikāk] & (noun) & 'friction' \\
\hline 2. & مَائعِع & [mā' $\left.\mathrm{i}^{‘}\right]$ & (adjective) & 'fluid' \\
\hline 3. & نَنَبْنْبَ & [tadabdub] & (noun) & 'vibration' \\
\hline 4. & تَنَبْبْنَبَ & [tadabdaba] & (verb) & 'to vibrate' \\
\hline
\end{tabular}

IPA refers to https://www.internationalphoneticalphabet.org/ipasounds/ipa-chart-with-sounds/

The next example is presented the lexical categories

Tabel 2 the lexical categories

\begin{tabular}{|c|c|c|c|c|c|}
\hline No & $\begin{array}{l}\text { Lexical } \\
\text { category }\end{array}$ & & $\begin{array}{l}\text { Lexical } \\
\text { category }\end{array}$ & $\begin{array}{l}\text { Compound } \\
\text { word }\end{array}$ & Meaning \\
\hline 5. & إِحْتِكَاكَ & + & مَائعِ & إِحْنِكَالكَ مَائِعُ & $\begin{array}{l}\text { 'fluid } \\
\text { friction' }\end{array}$ \\
\hline & (noun) & + & (adj) & (noun + adj.) & \\
\hline 6. & تَنَبَْْبَبَ & + & الَقَّرَيٌّ & 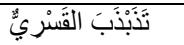 & \\
\hline & (verb) & + & (noun) & (noun + verb) & $\begin{array}{l}\text { 'forced } \\
\text { oscillatio } \\
\text { n' }\end{array}$ \\
\hline
\end{tabular}

This work explores the main compounding pattern of Arabic mechanical terms by documenting them from their lexicographic subject in the translation department. Thereby this article tries to fill the gap between experts because compound words do not receive much attention. Based on the statements above these writers are interested to analyze compound words in Dictionaries of Arabic Mu'jam Handasat al-Mikanik alMusowir in the subject of lexicography at $4^{\text {th }}$ semester in Arabic Translation Department, Syarif Hidayatullah State Islamic University Jakarta. By so doing, the writers give the title Compound Words in Arabic Mechanical Term.

\section{METHODOLOGY}

Apply the style as required based on the content and context. (Please don't highlight your text in yellow. This is descriptive qualitative research with a content analysis method to analyse the form and meaning mechanic compound words. The data source is categorised into primary and secondary. First data is vocabularies in mechanic dictionaries and CNN newspaper for the period 2018-2019. Secondary data resources relevant was taken from some references related to the concept of the compound word. The subject of this research is compound words. The objects of this research are the forms of compound words and the meanings of compound words. The data is collected by using the documentation method and note technique as mentioned by (Sudaryanto [16]). The writers performed several procedures to obtain the data. First, the writers read the dictionary many times to understand the whole Arabic mechanical term related to this study. Second, the writers identified the problem as the primary trouble. Third, the writers applied and synthesized the theory and the problem of the mechanic term. The fourth, the writer took note of the data found selecting compound words and retyping. The data is analysed by using a tree diagram (Plag's theory) and identifying meaning using Haspelmath's theory)

\section{FINDING AND DISCUSSIONS}

This study intends to answer two questions, namely (1) what are the types of compound words in Arabic mechanic terms?, and (2) what lexical categories are represented to convey the Arabic mechanic term? The results and discussion are as below.

\subsection{Finding}

Types of Compound Processes in Forming Arabic Mechanic Compound Words. There are three types of compound processes in forming Arabic mechanic compound words which were found by the researcher, namely Endocentric Compound, Exocentric Compound, and Copulative Compound. 


\subsubsection{Endocentric Compound}

Endocentric compound refers to a type of compound that means hyponym. Endocentric compounds are compounds consisting of a head and dependents (or several dependents) where the meaning of the semantic head is a hyponym of the overall meaning of the compound word as mentioned by (Haspelmath \& Sims, 2013, p. 327). Henceforth [5] describes a similar concept, an endocentric compound is a compound whose compound shows a hyponym of the head element in the compound Below are examples of endocentric compound words.

Table 3 the examples of the endocentric compound word

\begin{tabular}{|c|c|c|}
\hline No & Example & Meaning \\
\hline 7. & مِحْوَرٌ تِلِنْكُوُْبِي & 'telescope shaft' \\
\hline 8. & تَجَجربَةُ الصَّلَادَدةٍ & 'hardness tester' \\
\hline 9. & 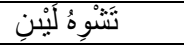 & 'plastic deformation' \\
\hline 10. & 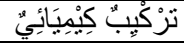 & 'chemical composition; \\
\hline 11. & حَلِيْدُ الصَبَّب & 'cast iron' \\
\hline 12. & حَرِيدٌ غَامَا & 'gamma iron' \\
\hline 13. & فُوُْو لَاذِ كَرْبُوْنِيَ & "carbon steel' \\
\hline 14. & بُجَارُ الزَيْتِ & 'oil mist' \\
\hline 15. & 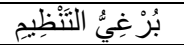 & 'set screw' \\
\hline
\end{tabular}

The examples listed in table 1 show that the core words of the endocentric compound are on the right. It means that the word has considered endocentric when the first word serves as a modifier of the second word or the head that determine the meaning of the head more precisely.

\subsubsection{Exocentric Compound}

The exocentric compound is one of the types of compounds which does not contain a headword and dependent word [5]. Exocentric compound refers to something which is not a sub-class of either the elements in the compound, that is they are not hyponyms of either of their elements Below are examples of exocentric compound words.

Table 4 the examples of the endocentric compound word

\begin{tabular}{|c|c|c|}
\hline No & Example & Meaning \\
\hline 16. & حَخَّ العَمَلِ & 'continuous mark made on a surface line' \\
\hline 17. & عَامِل السَحَب & 'a characteristic part of something' \\
\hline 18. & دوَُرَة كرنو & 'turn in a course' \\
\hline 19. & مُسُخَنِن بََبَئي & 'hot water throws u \\
\hline
\end{tabular}

\subsection{Discussion}

Based on the data analysis, the writer discusses the result of the study. Based on the discussion, the writer discusses the recapitulation of the result of the study. The writer finds three forms of the compound word. The forms are noun compound, verb compound and adjective compound. The writers find three forms of mechanic compound words. The forms are 1) noun compound, 2) verb compound and 3) Conjunctive compound noun. Below is the explanation of each type of category.

\section{Noun Compound}

Noun compound is a word-forming process made up of more than one word and functions as a noun. There are several ways to form a noun compound. Those are in table 5 as follows:

Table 5 the examples of noun compound word

\begin{tabular}{|c|c|c|c|c|c|c|c|c|c|}
\hline \multicolumn{10}{|c|}{ Example } \\
\hline 16. & Noun & (س) & + & Noun & (سن) & $\rightarrow$ & Noun & (w) & Meaning \\
\hline & إنجال & & + & نشألبئ & & & 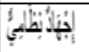 & & 'nomal stress' \\
\hline \multirow[t]{2}{*}{17.} & Adjective & (نون) & + & Noun & (س) & $\rightarrow$ & Noun & (س) & \\
\hline & سִ & $\mathrm{Sg}$ & + & 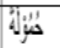 & & & 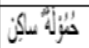 & & 'static loading' \\
\hline \multirow[t]{3}{*}{18.} & Verb & (b) & + & Noun & (س) & $\rightarrow$ & Noun & (w) & \\
\hline & لَّقى & & + & إنها & & & 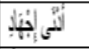 & & 'minimum stress' \\
\hline & جن & & & ر & & & جسرّز & & 'ffee body' \\
\hline \multirow[t]{2}{*}{19.} & Noun & ( ل & + & $\mathrm{Adj}$ & $(\mathrm{U}-\mathrm{g})$ & & Noun & ( & \\
\hline & 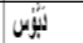 & & + & ضُض & & & 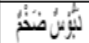 & & 'dorrel pin' \\
\hline
\end{tabular}

Here, the writer presents one example of noun compound in tree diagram 1a and $1 \mathrm{~b}$

a. تَرَدَّدُ طَبِيْعِيُّ 'natural frequency', it is in tree diagram 1a

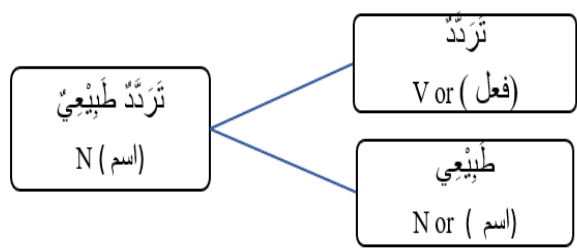

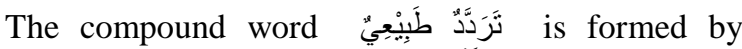

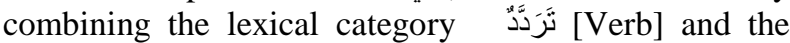
lexical category نَبيعيّ [Noun]. The word means 'to hold back, to circulate, to dither, to hesitate, to patronize, to vacillate, to waver, to be of two minds, to frequent.' The word طَي woun as [Noun means 'normal,

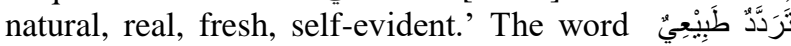
means details of a 'natural frequency'. It does not mean اسم asers to 'hesitancy, hesitation, indecision, irresolution, vacillation, vibration.' In brief, the combination of the two elements bring new meaning.

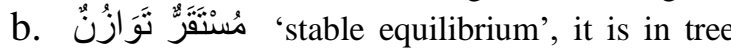
diagram $1 b$ 


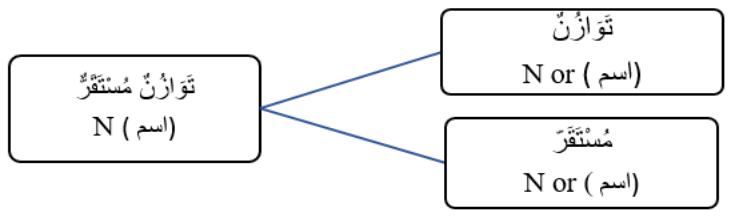

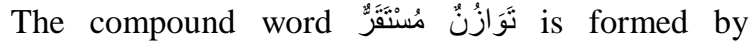
combining the lexical word نَوَازُنُّنُ [tawāzun] is (Noun)

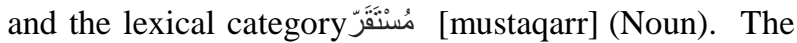

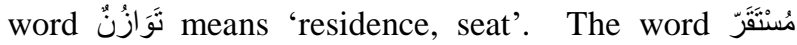

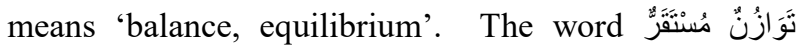
means details of a 'natural frequency'. It does not mean

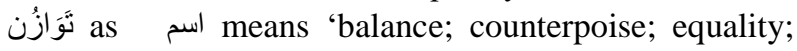
equilibrium, equipoise; evenness; poise.' Based on this analysis, the combination of the two elements brings new meaning namely 'stable equilibrium.'

\section{Verb Compound}

Verb compound is a verb that comprises of couple words. Compound verbs are commonly set up with a hyphen. Most compound verbs comprise a noun phrase along with a verb. In process of verbs, they can be transitive (متعد فعل) (مُنَعَدِّية أَفْعال) intransitive. For الكلب أَنْوَر ضَرَبَ means 'Anwar (S) hits (V) the dog (O). Further verbs

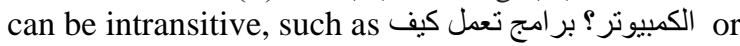

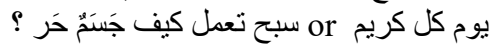

There are four ways to form verb compounds in Arabic mechanic terms. Those are in table 6 as follows:

Table 6 the example of verb compound

\begin{tabular}{|c|c|c|c|c|c|c|c|c|}
\hline \multicolumn{9}{|c|}{ Example } \\
\hline$\div$ & & & & & & & & \\
\hline \multirow[t]{3}{*}{20.} & Noun & (اسم) & + & Verb & (i) & $\rightarrow$ & Verb & Meaning \\
\hline & | غطالA / & (سم) & + & | & (i) & $\rightarrow$ & 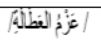 & 'moment of inertia' \\
\hline & | الألبَّة|ه| & (السم) & + & 每 & (bi) & $\rightarrow$ & 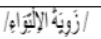 & 'angel of torsion' \\
\hline \multirow[t]{3}{*}{21.} & Verb & (فل (نل) & + & Adj & (نونت) & $\rightarrow$ & Verb & \\
\hline & | لكريجيا / & (فل (ن) & + & 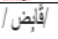 & (نون (نو) & $\rightarrow$ & 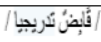 & 'friction clutch' \\
\hline & | بَسنَ/ & (فل (ف) & + & المُرْ | & (نوبن) & $\rightarrow$ & 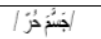 & 'footlose' \\
\hline \multirow[t]{2}{*}{22.} & Verb & (فل (ف) & + & Noun & (نون & & & \\
\hline & | مزكة | & (ف) & + & 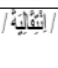 & (نون (نو) & $\rightarrow$ & 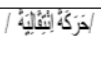 & $\begin{array}{l}\text { 'translational } \\
\text { motion' }\end{array}$ \\
\hline
\end{tabular}

Here, the writer presents one example analysis of verb compound.

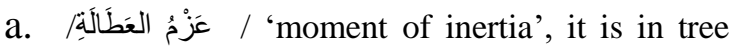
diagram $2 \mathrm{a}$

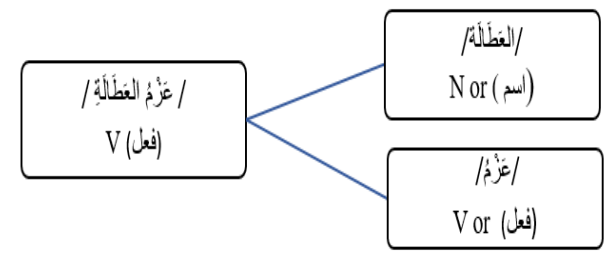

The compound word عَزَمُ العَطالةِ is formed by combining the lexical word عَزُْْ is (verb) and العَطَالَة is (noun). The word عَ means 'to set out to do something, enchant; spellbind.' The word العَطَالَة ' means 'inertia, joblessness, inactivity'. In brief, the compound word عَزُْمُ العَطَالَّلَ consist of two lexical items. These words occur together to express a specifically meaning. It does not mean العَطَالَة as noun or (اسم a (الَم

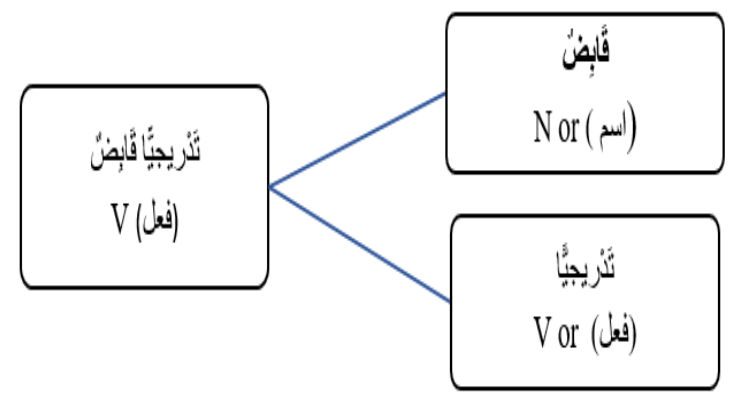

means 'unemployment, inactivity' and the expresses 'enchant.' Shortly, the two elements combine in harmony to deliver new meaning namely 'moment of inertia.'

b. قَابِضْ تَنْريجيًَا 'friction clutch', it is tree diagram $2 b$

The compound word قَابِضُ تَذْريجيًّا is formed by combining the lexical word قَذَّريجًَ is (verb). The word قَابِض means 'controlling, dominant, dominating, holding.' The word 'نَّريجيَّا 'means 'step by step, to increase, to improve, to transform, to explain'. In brief, the compound word قَابِضُ تَذْريجيَّا consist of two lexical constituents. These words occur together to express a peculiar meaning. It does not mean قَابِض as noun or (اسم ) means 'holding, controlling' and the تَنْريجيًّا combine in harmony to deliver new meaning namely 'friction clutch.'

\section{Conjunctive Compound Noun}

There are four ways to form verb compound in Arabic mechanic term. Those are in table 7 as follows: 
Table 7 the example of conjunctive compound noun

\begin{tabular}{|c|c|c|c|c|c|c|c|c|c|c|}
\hline 23. & Noun & + & Noun & + & Conj & + & Noun & $\rightarrow$ & Noun & Meaning \\
\hline & 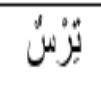 & + & لُولْبي & + & 2 & + & حُلُْونٌ & $\rightarrow$ & & 'spiral gear' \\
\hline 24 & 年 & $t$ & 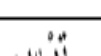 & & & & & & 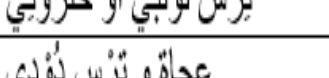 & 'worm anor' \\
\hline 24. & باسلا & + & البرس & + & 9 & $\dagger$ & لودلى & $\rightarrow$ & عجاهو برَس لؤلدي & "worm gear' \\
\hline & Noun & + & Noun & + & Prep & + & Noun & & Noun & \\
\hline 25 . & الجزَه| & + & |نشيت & + & بِن & + & مُرَرَك كُ & $\rightarrow$ & 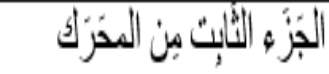 & 'engine' \\
\hline 26. & صماء & + & النَكَكُّ & + & في & + & الضَنَطُ & $\rightarrow$ & 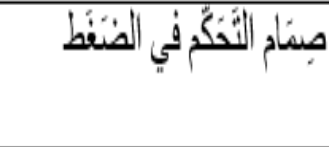 & $\begin{array}{l}\text { 'pressure } \\
\text { control valve }\end{array}$ \\
\hline
\end{tabular}

The conjunctive compound word عجاة و تِرْس دُودي is formed by combining the lexical word عجاة is (noun),

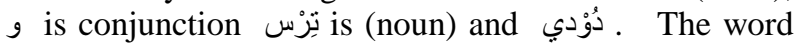

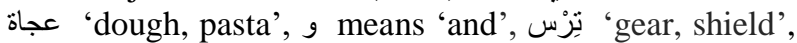
دُؤدي 'wormy, marked with close wavy lines'. As result, the conjunctive compound noun عجاة و تِرْس دُوْدي consist of three lexical constituents. These words occur together to indicate a distinctive meaning. The composition of the four elements combines in harmony to convey a new meaning namely 'worm gear.' In a few words, this analysis found that there are three types of compound words in the mechanical field, namely noun, verb, and conjunctive. This finding also shows that a) adjacency or closeness shows that no intervening elements can be inserted between the head and the non-head of compounds, b) contrast with referentiality reveals that insertion is allowed in the phrase. These findings are different from sBounhas and Slimani (2009). It has quoted by Omar \& Al-Tashi [13] who said the Arabic noun compound has five classes. She described it, such

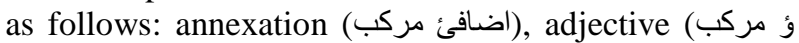
(صفئ), prepositional (مجرؤرة مركبة اسماء), conjunctive (موصؤلة مركبة اسماء), compound nouns linked by composite relations (العلاقات مجمعة مركبة اسماءة).

\section{CONCLUSION}

After finding and analyzing mechanic compound words in Dictionaries of Arabic Mu'jam Handasat alMikanik al-Musowir by applying word-formation of Plag's theory and the semantic grammatical Nick Riemer's theory. It can be concluded that there are three types of mechanic term compound words based on semantics grammatical categories. Each type is categorized into different lexical categories. Lexical categories that often appear to form mechanic compound words are such as nouns, verbs, adjectives, conjunctions, and prepositions.

\section{AUTHORS' CONTRIBUTIONS}

The authors' contribution explains mechanical terms in Arabic can be considered as part of the formation of complex compound words in the Arabic language because it has various forms. From the point of view of the Indonesian Arabic translator practitioner, the term mechanic is an important domain in realizing the actual contribution of Arabic lexicographic studies and practice understanding the process of word-formation.

\section{ACKNOWLEDGMENTS}

We would like to express our special thanks of gratitude to our lecturer (Ikhwan Azizi M.A) as well as our principal (Saiful Umam, PhD) who gave me the golden opportunity to do this wonderful project on the topic (Arabic Mechanical Term), which also helped us in doing a lot of research and we came to know about so many new things we are thankful to them. Secondly, we would also like to thank the KIMLI committee and friends who gave us a lot in finalizing this project within the limited time frame.

\section{REFERENCES}

[1] Najar, D., Mesfar, S., \& Ghezela, H. Ben. (2016). A large terminological dictionary of Arabic compound words. Communications in Computer and Information Science, 607, 16-28. https://doi.org/10.1007/978-3-319-42471-2_2

[2] Altakhaineh, A. R. M. (2016). Headedness in Arabic Compounds within the Synthetic Genitive Construction. SAGE Open, 6(4). https://doi.org/10.1177/2158244016674514

[3] Altakhaineh, A. R. M., \& Zibin, A. (2018). Verb + 
verb compound and serial verb construction in Jordanian Arabic (JA) and English. Lingua, 201, 45-56.

https://doi.org/10.1016/j.lingua.2017.08.010

[4] Mezghanni, I. B., \& Gargouri, F. (2017). Deriving ontological semantic relations between Arabic compound nouns concepts. Journal of King Saud University - Computer and Information Sciences, 29(2), 212-228. https://doi.org/10.1016/j.jksuci.2017.03.001

[5] Plag, I. (2003). Word Formation in English. Cambrdige University Press. www.cambridge.org

[6] Lieber, R. (2009). Introducing Morphology. In Introducing Morphology. Cambrdige University Press. https://doi.org/10.1017/cbo9780511808845

[7] Haspelmath, M., \& Sims, A. D. (2013). Understanding Morphology. In Understanding Morphology (tenth). Hodder Education. https://doi.org/10.4324/9780203776506

[8] Yule, G. of. (2010). The Study of Language (Fourth). Cambrdige University Press. www.cambrdige.org

[9] Awang, R., \& Salman, G. (2017). Translation and Arabicization Methods of English Scientific and Technical Terms into Arabic. Arab World English Journal For Translation and Literary Studies, 1(2), 92-106. https://doi.org/10.24093/awejtls/vol1 no2.8

[10] Harðarson, G. R. (2016). Peeling away the layers of the onion: on layers, inflection and domains in Icelandic compounds. Journal of Comparative Germanic Linguistics, 19(1). https://doi.org/10.1007/s10828-016-9078-5

[11] Jarrah, M., Abdulazeez, J., \& Alkhawaja, L. (2021). The position of the broken plural in the grammar: Rural Jordanian Arabic as a case study. Lingua, $x x x x$ 103165. https://doi.org/10.1016/j.lingua.2021.103165

[12] Booij, G. (2007). The Grammar of Words, 2nd edition ( and L. M. Keith Brown, Eve V. Clark, April McMahon, Jim Miller (ed.); second edi). Oxford University Press. https://www.pdfdrive.com/the-grammar-of-wordsan-introduction-to-linguistic-morphology-oxfordtextbooks-in-linguistics-d184130381.html

[13] Omar, N., \& Al-Tashi, Q. (2018). Arabic nested noun compound extraction based on linguistic features and statistical measures. GEMA Online Journal of Language Studies, 18(2), 93-107. https://doi.org/10.17576/gema-2018-1802-07

[14] Aronoff, M., \& Fudeman, K. (2011). What is morphology?

(second).

Blackwell. https://www.pdfdrive.com/what-is-morphologyd14605659.html

[15] Reimer, N. (2010). Introducing Semantics. Cambrdige University Press. www.cambridge.org

[16] Sudaryanto. (2015). Metode Linguistik: Ke Arah Memahami Metode Linguistik. Gajah Mada University Press. 